\title{
Nonlinear and linear models estimating the body weight of bovine cattle in the tropics from thoracic perimeter
}

\author{
*Julio Cesar Vinay-Vadillo ${ }^{1}$, Benjamín Alfredo Piña-Cárdenas ${ }^{1}$, Gwendolyne Peraza-Mercado ${ }^{2}$, José Javier \\ G. Canton-Castillo ${ }^{1}$ and Jorge Hernández-Bautista ${ }^{3}$ \\ ${ }^{1}$ Instituto Nacional de Investigaciones Forestales, Agrícolas y Pecuarias. México \\ ${ }^{2}$ Universidad Autónoma de Ciudad Juárez, Chihuahua. México \\ ${ }^{3}$ Universidad Autónoma Benito Juárez de Oaxaca. México
}

\begin{abstract}
Article history
Received: 10 Dec, 2015

Revised: 23 Jan, 2016

\section{Abstract}

The objective was to determine the best nonlinear and linear model to estimate the Accepted: 24 Feb, 2016 body weight (BW) of males and females of Holstein (Ho) and Brown Swiss (BS) crossed with Zebu $(\mathrm{Z})$ cattle under two management systems, measuring the thoracic perimeter (TP). 1577 observations of $\mathrm{BW}$ and TP measurements from the male and female BS and Ho crossed with Z cattle under two management systems (Estación Experimental La Posta and Matias Romero). Measurements were taken every 28 days from 2006 to 2008 year. An analysis of nonlinear regression of the models, Gamma Function, Brookes and the multiplicative was performed with the software Scientist, which obtained the coefficients $a, b, c$ and the indicators of goodness of fit MSC, R, $\mathrm{R}^{2}, \mathrm{C}$ and multiple linear regression of the body weight (BW) vs thoracic perimeter (PT) in its linear and quadratic form. To the nonlinear model variables a completely randomized experimental design was applied, having the factors: model, gender and management systems. The results showed that there was no statistically significant difference $(\mathrm{P} \geq 0.05)$ among the factors, models and management systems for the analyzed variables, although for the factor gender, male data adjusted better than females data in predicting body weight from thoracic perimeter. TP and $\mathrm{TP}^{2}$ were significant $(\mathrm{P} \leq 0.05)$ in the estimation of body weight. The nonlinear model of the gamma function and linear TP-TP ${ }^{2}$ properly estimate the body weight from chest circumference for cattle in the Mexican tropics.

Keywords: Cattle; nonlinear models; thoracic perimeter; linear model
\end{abstract}

\begin{abstract}
To cite this article: Vinay-Vadillo JC, BA Piña-Cárdenas, G Peraza-Mercado, JJG Canton-Castillo and J Hernández-Bautista, 2016. Nonlinear and linear models estimating the body weight of bovine cattle in the tropics from thoracic perimeter. Res. Opin. Anim. Vet. Sci., 6(1): 19-23.
\end{abstract}

\section{Introduction}

Knowledge of cattle's body weight (BW) is considered of great importance as it is a tool that leads to the overall improvement of systems of tropical, dairy in growth evaluation, planning of nutrition, reproduction and animal health in the different categories of animals, the establishment of homogeneous flocks, the use of food resources, the application of medicine, observation and breeding. However, implementation of technology requires the use of scales that represent a high cost for

\footnotetext{
*Corresponding author: JC Vinay- Vadillo, Campo Experimental La Posta. Instituto Nacional de Investigaciones Forestales Agrícolas y Pecuarias Paso del Toro, Medellín. Veracruz. México; E-mail: vinay.julio@inifap.gob.mx jcvavi@gmail.com
} 
producers in developing countries, limiting their presence in dairy tropical systems. The most used zoometric measures that have been significant to estimate the body weight of cattle were chest circumference and height at the withers (Alderson, 1999; Mahecha et al., 2002; Saacti and Tilki, 2007). The models that have been used to estimate the BW from the chest circumference are polynomial and exponential. Garcia et al. (2009) conducted an evaluation of different polynomial models to predict the body weight from the chest circumference and found that the multiplicative mathematical model showed the best correlation coefficient for Holstein females. In the case of exponential models, Mahecha et al. (2002) (Gamma function) and Mauricio and Rodríguez (1996) using the method proposed by Brookes and Harrington (1960) found good fits, with results of $95 \%$ confidence in the estimation of cattle's body weight. Therefore, it was established as objective to determine the body weight of males and females HoxZ and BSxZ in dairy tropical system measuring chest circumference, by means of different models in the management systems of dual purpose in the Mexican tropic.

\section{Materials and Methods}

This research was conducted at the Experimental Stations (ES) La Posta and Matias Romero of the National Research Institute of Forestry, Agriculture and Livestock (INIFAP-Instituto Nacional de Investigaciones Forestales Agrícolas y Pecuarias-) through the years 2006 to 2008. The ES La Posta is located at $\mathrm{Km} 22.5$ on the Veracruz -Cordoba highway, Paso del Toro, Medellin, Veracruz. It is located at latitude $19^{\circ} 00^{\prime} 49^{\prime \prime}$ and longitude $96^{\circ} 08^{\prime} 19^{\prime \prime}$ with a height of 10 meters above sea level (INEGI, 2009). The climate is warm sub-humid $\mathrm{Aw}_{2}$ type, with an average annual rainfall of $1461 \mathrm{~mm}$, relative humidity of $77.4 \%$ (Vidal, 2005), and average temperature of $25^{\circ} \mathrm{C}$. The ES Matias Romero is at $152.5 \mathrm{Km}$ of the Transísmica Coatzacoalcos-Salina Cruz Highway, Matias Romero, Oaxaca, at latitude $17^{\circ} 12^{\prime} 05^{\prime \prime}$, longitude $95^{\circ} 03^{\prime} 04^{\prime \prime}$ and a height of 50 meters above sea level (INEGI, 2009). The climate is hot and humid Am type, with an average annual temperature of $25.6^{\circ} \mathrm{C}$ and average annual rainfall of $2250 \mathrm{~mm}$. Herds from ES La Posta and ES Matias Romero had genotypes HoxZ and BSxZ. They were managed under intensive rotational grazing with electric fencing, feeding was grazing on Pangola (Digitaria decumbens), Taiwan (Pennisetum purpureum), Africa star grass (Cynodon plectostachyus), Signal (Brachiaria decumbens), Insurgent (Brachiaria brizantha) and Tanzania (Panicum maximum cv. Tanzania) and on the critical dry season they were supplemented with a diet based on corn or sorghum silage. The measurement of weight and chest circumference was performed every 28 days, from weaning to 36 months of age, using a Truper ${ }^{\circledR}$ fiberglass measuring tape, graduated on both sides and a Tru-Test electronic scale with capacity of $1500 \mathrm{~kg}$. 1,577 records of male and female cattle (HoxZ and BSxZ) under two management systems were used in total: the ES La Posta had an average daily weight gain of $300 \mathrm{~g}$ and the ES Matias Romero had daily gains of $400 \mathrm{~g}$.

Nonlinear models used are described below.

$B W=\exp a(\ln T P)+b T P+c ;$ Brookes and Harrington (1960)

$B W=a \exp ^{b T P} T P^{c} ;$ Gamma Function, cited by Mahecha et al. (2002)

$B W=a T P^{b} ;$ Multiplicative

Where: $\mathrm{BW}=$ Body weight $\mathrm{TP}=$ Thoracic perimeter; $\mathrm{a}, \mathrm{b}, \mathrm{c}=$ Coefficients

A nonlinear regression analysis was performed with each one of the models, for which the Scientist software was used, with this the coefficients a, b, c, were obtained for the factors used generating the prediction equations. In addition, a goodness of fit test was applied using a residual analysis as model selection criterion (MSC), the coefficient of determination (R), $\mathrm{R}^{2}$ and correlation (C). Also the $\mathrm{X}^{2}$ test was carried out to verify whether there was difference between the estimated value and the observed value at a significance level of $95 \%$.

The MSC was used to define which of the model and equation better fit the observed data. The MSC provides categories between models as the Akaike information criterion that has been standardized and is independent of the data scale. In the study, generally the most appropriate model is the one with the highest MSC value (because the purpose is to maximize the information of the model) whose expression is as follows.

$$
M S C=\operatorname{Ln}\left[\frac{\sum_{i=1}^{n} W_{i}\left(Y_{o b s_{i}}-\bar{Y}_{o b s}\right)^{2}}{\sum_{i=1}^{n} W_{i}\left(Y_{o b s_{i}}-Y_{c a l_{i}}\right)^{2}}\right]-\frac{2 p}{n}
$$

Where: $\mathrm{Ln}=$ Natural logarithm, $\mathrm{n}=$ Number of points, $\mathrm{W}_{\mathrm{i}}=$ Weight applied to each point.

$\underline{\mathrm{Y}}_{\mathrm{cal}}=$ Calculated weight, $\mathrm{Y}_{\mathrm{obs}}=$ Observed weight.

$p=$ Number of parameters (equivalent to the number of degrees of freedom).

The experimental design applied was completely randomized, with factors as models, gender, and system management (SM). 
Res. Opin. Anim. Vet. Sci., 2016, 6(1): 19-23.

Table 1: Effect of the different models on indicators of goodness of fit for body weight and thoracic perimeter of Holstein and Brown Swiss crossed with Zebu in tropical dairy

\begin{tabular}{|c|c|c|c|c|c|c|}
\hline \multirow{2}{*}{ Indicators of Goodness of fit } & \multicolumn{2}{|c|}{ Brookes $(1,577)$} & \multicolumn{2}{|c|}{ Gamma $(1,577)$} & \multicolumn{2}{|c|}{ Multiplicative $(1,577)$} \\
\hline & Mean & SEM & Mean & SEM & Mean & SEM \\
\hline MSC & $2.32^{\mathrm{a}}$ & 0.064 & $2.35^{\mathrm{a}}$ & 0.064 & $2.35^{\mathrm{a}}$ & 0.064 \\
\hline $\mathrm{R}$ & $0.9082^{\mathrm{a}}$ & 0.00658 & $0.9032^{\mathrm{a}}$ & 0.00658 & $0.9028^{\mathrm{a}}$ & 0.00658 \\
\hline $\mathrm{R}^{2}$ & $0.9946^{\mathrm{a}}$ & 0.00035 & $0.9941^{\mathrm{a}}$ & 0.00035 & $0.9939^{\mathrm{a}}$ & 0.00035 \\
\hline Correlation, $\mathrm{C}$ & $0.9511^{\mathrm{a}}$ & 0.00590 & $0.9505^{\mathrm{a}}$ & 0.00590 & $0.9397^{\mathrm{a}}$ & 0.00590 \\
\hline
\end{tabular}

${ }^{\mathrm{a}, \mathrm{b}}$ Different letters between columns imply statistical difference $(\mathrm{P} \leq 0.05)$. Means were compared by the Tukey method. SEM $=$ Standard Error of the Mean. () = Number of observations.

Table 2: Effect of two different management systems on indicators of goodness of fit for body weight and thoracic perimeter of Holstein and Brown Swiss $x$ Zebu cattle in tropical dairy

\begin{tabular}{|c|c|c|c|c|}
\hline \multirow{2}{*}{ Indicators of Goodness of fit } & \multicolumn{2}{|c|}{ ES La Posta (885) } & \multicolumn{2}{|c|}{ ES Matías Romero (640) } \\
\hline & Mean & SEM & Mean & SEM \\
\hline MSC & $2.34^{\mathrm{a}}$ & 0.058 & $2.34^{\mathrm{a}}$ & 0.047 \\
\hline $\mathrm{R}$ & $0.9037^{\mathrm{a}}$ & 0.00597 & $0.9058^{\mathrm{a}}$ & 0.00487 \\
\hline $\mathrm{R}^{2}$ & $0.9939^{\mathrm{a}}$ & 0.00032 & $0.9944^{\mathrm{a}}$ & 0.00026 \\
\hline Correlation, $\mathrm{C}$ & $0.9483^{\mathrm{a}}$ & 0.00535 & $0.9459^{\mathrm{a}}$ & 0.00437 \\
\hline
\end{tabular}

${ }^{a, b}$ Different letters between columns imply statistical difference $(\mathrm{P} \leq 0.05)$. Means were compared by the Tukey method. SEM = Standard Error of the Mean. () = Number of observations.

Table 3: Effect of gender on indicators of goodness of fit for body weight and thoracic perimeter of Holstein and Brown Swiss $X$ Zebu cattle in tropical dairy

\begin{tabular}{|c|c|c|c|c|}
\hline \multirow{2}{*}{ Indicators of Goodness of fit } & \multicolumn{2}{|c|}{ Females (652) } & \multicolumn{2}{|c|}{ Males (924) } \\
\hline & Mean & SEM & Mean & SEM \\
\hline $\mathrm{MSC}$ & $2.03^{b}$ & 0.052 & $2.66^{\mathrm{a}}$ & 0.052 \\
\hline $\mathrm{R}$ & $0.8750^{\mathrm{b}}$ & 0.00539 & $0.9345^{\mathrm{a}}$ & 0.00539 \\
\hline $\mathrm{R}^{2}$ & $0.9947^{\mathrm{b}}$ & 0.00029 & $0.9936^{\mathrm{a}}$ & 0.00029 \\
\hline Correlation, $\mathrm{C}$ & $0.9293^{\mathrm{b}}$ & 0.00484 & $0.9650^{\mathrm{a}}$ & 0.00484 \\
\hline
\end{tabular}

${ }^{a, b}$ Different letters between columns imply statistical difference $(\mathrm{P} \leq 0.05)$. Means were compared by the Tukey method. SEM = Standard Error of the Mean. () = Number of observations.

$Y_{i j k l}=\mu+M_{i}+S_{j}+S M_{k}+\xi_{i j k l}$

$\mathrm{Y}_{\mathrm{ijkl}}=$ Response variables (MSC, $\mathrm{R}, \mathrm{R}^{2}$ y C)

$\mu=$ Population mean, $\mathrm{M}_{\mathrm{i}}=$ Models, $\mathrm{S}_{\mathrm{j}}=$ Gender, $\mathrm{SM}_{\mathrm{k}}=$

Management system

$\xi_{\mathrm{ijkl}}=$ Experimental error

A multiple linear regression analysis and the corresponding analysis of variance was performed to determine if both or one of them was significantly important in the equation of body weight vs thoracic perimeter in its linear (TP) and quadratic $\left(\mathrm{TP}^{2}\right)$ forms, evaluating autocorrelation and independence with the Durbin-Watson (d) statistic, this was applied for the factors: genotype, gender and ES.

\section{Results and Discussion}

Table 1 shows the results of the effect of the different mathematical models on indicators of goodness of fit, related to the chest circumference and body weight of European cattle (Holstein and Brown Swiss) crossed with Zebu. The MSC results indicate a good fit, but they are statistically equal $(\mathrm{P} \geq 0.05)$ among the models used, protruding models Gamma Function and the Multiplicative with values of 2.35 both.

In the case of $\mathrm{R}, \mathrm{R}^{2}$ and $\mathrm{C}$ in the models no statistical differences $(\mathrm{P} \geq 0.05)$ were present, exceeding the levels of 0.9 each one. Although there was no significant difference between the tested models, regardless they can predict body weight from the chest circumference, which confirms the results found by Mahecha et al. (2002) and Colin et al. (2010) in the case of the Gamma function model and Solis et al. (1987) and Garro and Rosales (1996) for the model proposed by Brookes.

The results of the effect of two different management systems on the indicators of goodness of fit, body weight and chest circumference of bovine HoxZ and BSxZ in tropical dairy are shown in Table 2. It is noted that there was no statistical difference $(\mathrm{P} \geq 0.05)$ between the management system practiced in the ES La Posta and ES Matias Romero for the MSC indicator.

In Table 3 a statistically significant difference $(\mathrm{P} \leq 0.05)$ is observed in the MSC value, in the case of males as they have a better fit (2.66) than females (2.03), this was also evident for the value $\mathrm{R}(0.934)$ where in males a better performance was found than in females (0.875). 
Table 4: Multiple linear regression analysis, $t \mathrm{t} \mathrm{tp}^{2}$, for the factors genotype, gender and management system

\begin{tabular}{|c|c|c|c|c|c|c|c|c|}
\hline Genotype & Gender & MS & $\mathrm{n}$ & TP & $\mathrm{TP}^{2}$ & Predictive Model & $\mathrm{R}^{2}$ & $d$ \\
\hline $\mathrm{Ho} / \mathrm{Z}$ & $\mathrm{F}$ & Matías & 233 & & $*$ & $-23-0.20 \mathrm{PT}+0.0141 \mathrm{PT}^{2}$ & 0.90 & 1.08 \\
\hline $\mathrm{Ho} / \mathrm{Z}$ & M & Matías & 166 & & $*$ & $25-1.84 \mathrm{PT}+0.0233 \mathrm{PT}^{2}$ & 0.91 & 1.79 \\
\hline $\mathrm{BS} / \mathrm{Z}$ & $\mathrm{F}$ & Matías & 101 & & $*$ & $196-3.1 \mathrm{PT}+0.0236 \mathrm{PT}^{2}$ & 0.88 & 1.45 \\
\hline $\mathrm{BS} / \mathrm{Z}$ & M & Matías & 161 & & & $-177+1.17 \mathrm{PT}+0.0127 \mathrm{PT}^{2}$ & 0.88 & 1.46 \\
\hline $\mathrm{Ho} / \mathrm{Z}$ & $\mathrm{F}$ & Posta & 200 & & & $18-1.17 \mathrm{PT}+0.0183 \mathrm{PT}^{2}$ & 0.84 & 1.57 \\
\hline $\mathrm{Ho} / \mathrm{Z}$ & $\mathrm{M}$ & Posta & 417 & & * & $-36.4+0.5 \mathrm{PT}+0.0166 \mathrm{PT}^{2}$ & 0.94 & 1.77 \\
\hline $\mathrm{BS} / \mathrm{Z}$ & $\mathrm{F}$ & Posta & 86 & & * & $363-5.98 \mathrm{PT}+0.0355 \mathrm{PT}^{2}$ & 0.85 & 1.56 \\
\hline $\mathrm{BS} / \mathrm{Z}$ & $\mathrm{M}$ & Posta & 213 & & & $-32-0.76 \mathrm{PT}+0.0186 \mathrm{PT}^{2}$ & 0.91 & 1.97 \\
\hline
\end{tabular}

$\mathrm{Ho}=$ Holstein, $\mathrm{BS}=$ Brown Swiss, $\mathrm{Z}=$ Zebu, $\mathrm{F}=$ Female, $\mathrm{M}=$ Male, $\mathrm{TP}=$ Thoracic perimeter, $\mathrm{R}^{2}=$ Coefficient of Determination, $d=$ Durbin-Watson, * $(\mathrm{P} \leq 0.05)$.

Table 5: Multiple linear regression analysis, $t \mathrm{tp} \mathrm{tp}^{2}$, for the factors genotype and gender

\begin{tabular}{ccccccccc}
\hline Genotype & Gender & $\mathrm{EF}$ & $\mathrm{n}$ & $\mathrm{TP}$ & $\mathrm{TP}^{2}$ & Predictive Model & $\mathrm{R}^{2}$ & $d$ \\
\hline $\mathrm{Ho} / \mathrm{Z}$ & $\mathrm{F}$ & - & 433 & & $*$ & $-101-0.55 \mathrm{PT}+0.0125 \mathrm{PT}^{2}$ & 0.89 & 1.30 \\
$\mathrm{Ho} / \mathrm{Z}$ & $\mathrm{M}$ & - & 583 & $*$ & $-16.4-0.924 \mathrm{PT}+0.0187 \mathrm{PT}^{2}$ & 0.92 & 1.60 \\
$\mathrm{BS} / \mathrm{Z}$ & $\mathrm{F}$ & - & 187 & $*$ & $120-2.18 \mathrm{PT}+0.0209 \mathrm{PT}^{2}$ & 0.89 & 1.44 \\
$\mathrm{BS} / \mathrm{Z}$ & $\mathrm{M}$ & - & 374 & $*$ & $-177+1.17 \mathrm{PT}+0.0127 \mathrm{PT}^{2}$ & 0.88 & 1.46 \\
\hline
\end{tabular}

$\mathrm{Ho}=$ Holstein, $\mathrm{BS}=$ Brown Swiss, $\mathrm{Z}=$ Zebu, $\mathrm{F}=$ Female, $\mathrm{M}=$ Male, $\mathrm{TP}=$ Thoracic perimeter, $\mathrm{R}^{2}=$ Coefficient of Determination, $d=$ Durbin-Watson, * $(\mathrm{P} \leq 0.05)$.

Table 6: Multiple linear regression analysis, $t \mathrm{tp} \mathrm{tp}^{2}$, for the factor genotype

\begin{tabular}{ccccccccc}
\hline Genotype & Gender & $\mathrm{EF}$ & $\mathrm{n}$ & $\mathrm{TP}$ & $\mathrm{TP}^{2}$ & Predictive Model & $\mathrm{R}^{2}$ & $d$ \\
\hline $\mathrm{Ho} / \mathrm{Z}$ & - & - & 1016 & $*$ & $*$ & $33.6-1.55 \mathrm{PT}+0.0205 \mathrm{PT}^{2}$ & 0.92 & 1.46 \\
$\mathrm{BS} / \mathrm{Z}$ & - & - & 561 & $*$ & $*$ & $79.9-2.25 \mathrm{PT}+0.0236 \mathrm{PT}^{2}$ & 0.90 & 1.62 \\
\hline
\end{tabular}

$\mathrm{Ho}=$ Holstein, $\mathrm{BS}=$ Brown Swiss, $\mathrm{Z}=$ Zebu, $\mathrm{F}=$ Female, $\mathrm{M}=$ Male, $\mathrm{TP}=$ Thoracic perimeter, $\mathrm{R}^{2}=$ Coefficient of Determination, $d=$ Durbin-Watson, * $(\mathrm{P} \leq 0.05)$.

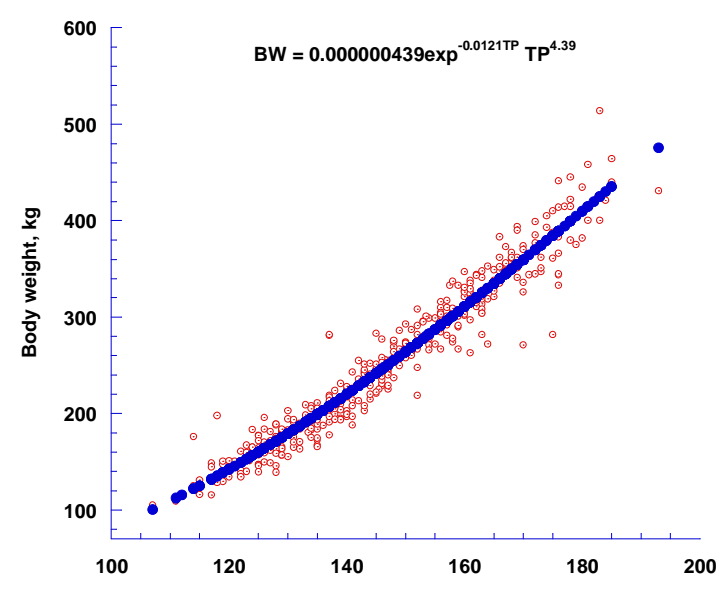

Fig. 1: Graph relating body weight and thoracic perimeter of bovines in tropical dairy

For the other variables such as $\mathrm{R}^{2}$ and $\mathrm{C}$ the same trend was present, that is, the best performance of the observed data fitting models to predict body weight was observed in males in both experimental fields or two different management systems.

The results of the Chi square test performed on the observed data and estimated by the models proposed by Brookes and Harrington, of the gamma function and multiplicative in HoxZ and BSxZ cattle of females and males in both management systems, indicate that there was no statistical difference between the observed and estimated body weights with a confidence level of $95 \%$, being consistency among data.

In Figure 1, the graph of body weight and thoracic perimeter of bovines kept in tropical dairy systems with the Gamma Function model is observed, dark points refer to the data obtained with the adjustment by the exponential equation, and lighter points are the observed data.

Table 4 shows the results of the quadratic polynomial regression analysis of TP for the genotype, gender and EF. It is noted that the response variable TP, in its linear form, was not significant $(\mathrm{P} \geq 0.05)$ for any of the factors. In the quadratic form it was significant $(\mathrm{P} \leq 0.05)$ for the prediction equation of body weight in male (HoxZ) and females (BSxZ) from the EF Matias Romero. For HoxZ genotypes males and females from the EF La Posta, variable $\mathrm{TP}^{2}$ was also significant $(\mathrm{P} \leq 0.05)$. Khalil and Vaccaro (2002) using dual purpose Venezuelan cows, included a second measure of TP, noting that the inclusion of the body length improved the accuracy of the prediction equation $\left(\mathrm{R}^{2}=\right.$ 0.87 vs 0.89 ), which revealed the non-compensation to take more zoometric measures, since a very slight increase of the estimator $\mathrm{R}^{2}$ occurred (Garcia et al., 2009).

In Table 5, it is observed that in the quadratic form TP was significant $(\mathrm{P} \leq 0.05)$, for the polynomial model with body weight, for the combined effect of genotype and gender. The autocorrelation is lower for females in both genotypes, but males with both genotypes are 
considered independent because the values are between 1.5 and 2.5 .

In Table 6 , the results of the polynomial regression analysis $\mathrm{TP}-\mathrm{TP}^{2}$ is presented. For genotype factor, thoracic perimeter in its linear and quadratic form is significant $(\mathrm{P} \leq 0.05)$. It is further noted that the $\mathrm{R}^{2}$ value was greater than 0.90 , indicating a good correlation between body weight and TP in the linear and quadratic form. D values indicate a slight autocorrelation. Mauricio and Rodrigo (1996) cited by Garcia et al. (2009), worked with Zebu cattle, using 2105 animals obtained confirmation that the best predictor of weight is the TP with a coefficient of determination of $\mathrm{R}^{2}=$ 0.92 .

\section{Conclusion}

In selecting the best model to predict body weight, it was considered to choose the Gamma Function, although not statistically different, but showed the highest values in the indicators of goodness of fit and also did not present statistical difference in the Chi Square test. The estimation of body weight can also be done using the thoracic perimeter with the linear model $\mathrm{TP}, \mathrm{TP}^{2}$ in cattle genotypes HoxZ and BSxZ in the tropics, the latter being a better option for ease of calculation.

\section{References}

Alderson GLH (1999) The development of a system of linear measurements to provide an assessment of type function of beef cattle. Anim Gen Resour Inform 25: 45-55.

Brookes, J, Harrington G (1960) Studies in beef production. II The estimation of live weight of beef steers from chest girth and other body measurements. J Agric Sci 5: 144-151.

Colin IBC, Vinay JCV, Dominguez BM, Cervantes PA, Bautista JH (2010) Perímetro torácico como estimador del peso vivo en bovinos machos cruzados en el trópico México. 2do. Congreso Internacional en Ciencias Veterinarias y Zootecnia. p. 5.

García LI, Vázquez MAF, Fernández EC, Vidal LG, García MTL de J (2009) Ecuaciones de predicción del peso vivo de hembras Holstein. Frisona Española. No. 171. www.revistafrisona.com. [Consulted in July 2015].

Mauricio GJ, Rodrigo RL (1996) Relación entre el peso corporal y el perímetro torácico en ganado Cebuino en crecimiento en Costa Rica. Agronomía Costarricense 20: 113-123.

Garro JM, Rosales LR (1996) Relación entre el peso corporal y el perímetro torácico en ganado Cebuino en crecimiento en Costa Rica. Agronomía Costarricense 20: 113-123.

INEGI (Instituto Nacional de Estadística y Geografía). 2009. Catalogo de claves de entidades federativas, municipio y localidades. [Consulted in August 2015] http://mapserver.inegi.org.mx/mgn2k/ $? \mathrm{~s}=$ geo $\& \mathrm{c}=1223$.

Khalil R, Vaccaro L (2002) Pesos y mediciones corporales en vacas de doble propósito; su interrelación y asociación con valor genético paratres características productivas. Revista Zootec Trop 20: 11-30

Mahecha L, Angulo J, Manrique LP (2002) Predicción del peso vivo a través del perímetro torácico en la raza bovina Lucerna. Revista Colombiana de Ciencias Pecuarias 15: 88-91.

Saacti M, Tilki M (2007) Zoometrical body measurements and their relation with live weight in native Turkish geese. Turk J Vet Anim Sci 31: 47-53

Solis G, Echandi OE, Arce C (1987) Estimación del peso corporal de ganado Cebuino y sus cruces por medición del perímetro torácico. Agronomía Costarricense 11: 131-140.

Vidal ZR (2005) Región 7, Golfo de México. pp: 121144. En: Las regiones climáticas de México. Instituto de Geografía UNAM, México. 